\title{
EFFECT OF CEMENT PRODUCTION ON VEGETATION IN A PART OF SOUTHWESTERN NIGERIA
}

\author{
AT Salami, AI Farounbi \\ Institute of Ecology and Environmental Studies, Obafemi Awolowo \\ University, Ile-Ife, Nigeria \\ JI Muoghalu \\ Department of Botany, Obafemi Awolowo University, Ile-Ife, Nigeria
}

\begin{abstract}
The impact of cement dust emissions from the factory of West African Portland Cement at Ewekoro in Southwestern Nigeria on the surrounding vegetation was investigated. Sample plots of $20 \mathrm{~m} \times 20 \mathrm{~m}$ were established at $1 \mathrm{~km}$ intervals from the factory site up to a distance of $10 \mathrm{~km}$ in the four cardinal directions. Leaves of common species were randomly selected for chlorophyll content analysis, leaf abundance and leaf area measurement. Woody as well as herbaceous species encountered within the established plots were enumerated, while soil samples (at $0-15 \mathrm{~cm})$ were collected for laboratory analysis. It was found that chlorophyll contents, leaf abundance, leaf area, woody species density and basal area increased significantly with increasing distance from the factory site. Organic matter, total nitrogen, $\mathrm{pH}$ and moisture contents of the top soil did not vary significantly across the study site. Available phosphorus decreased in concentration with increasing distance from the factory site. On the whole, cement dust deposition affected the vegetation parameters studied, up to a distance of $5 \mathrm{~km}$ from the factory site.
\end{abstract}

\section{INTRODUCTION}

Cement factories were established in Nigeria in response to the increased wave of construction after independence and during the oil boom era of the seventies (Oyedele et al. 1990). It has been shown that cement factories constitute one of the worst polluters in Nigeria today (Akeredolu et al. 1994). Establishment of these plants pre-dates strict industrial zoning regulations and hence their proximity to residential areas is now an issue of 
concern. For instance, West African Portland Cement Company (WAPCCO) commenced manufacturing in Nigeria with the commissioning of its first work at Ewekoro, Southwestern Nigeria in 1960. The factory now produces about 65 million tonnes of cement per year. The main ingredient of cement is limestone. For every tonne $(1000 \mathrm{~kg})$ of cement clinker, 1.25 tonnes of limestone, 0.23 tonne of clay, 0.04 tonne of silica stone and 0.03 tone of slag are ground, mixed and dried; then, they are heated in a cement kiln between $1400 ß C$ and $1500 ß C$. In this process, dust andsome metal pollutants such as mercury, cadmium, iron, calcium and potassium are released into the atmosphere (Fukuzaki et al. 1986, Akeredolu et al. 1994). The dust escaping from cement factories is often transported by wind and deposited in areas close and far away from the factory. These include agricultural lands, natural vegetation, towns and villages. Such depositions of particulate matter and other pollutants interfere with normal metabolic activities of plants, causing direct injury and impairment of growth and quality and may ultimately lead to decrease in plant yield.

The effect of direct cement dust particles on chlorophyll accumulation in leaves, for example, is two-fold. The concentrated dust particles in the atmosphere surrounding the plant reduce and probably screen out effective light rays reaching the leaves (Singh \& Rao 1981). Absence of such light rays would interfere with the pigment formation process and result in chlorotic plants. A second effect of the dust particles can be due to the encrustation of cement particles on the broad leaf surfaces (leaf blade), which will effectively seal out light penetration into the leaves. This would also retard chlorophyll synthesis in the leaves, leading to premature leaf yellowing and subsequent dropping of the stem. Chlorophyll biosynthesis is a good indicator of plant productivity as it represents the plant s potential in food manufacture. The present study assessed the extent to which cement dust deposition had impacted the vegetation of the study area.

\section{METHODS}

The study was carried out in Ewekoro, where the WAPCCO factory is located. The area lies between Latitudes $7^{0} \quad 10 \mathrm{~N}$ and $6^{\circ} 40 \mathrm{~N}$ and Longitudes $3^{0} 05 \mathrm{E}$ and $3^{0} 26 \mathrm{E}$. The present vegetation may be described as Derived Savanna and most part of the area was subject to annual burning. The climate is the humid sub-equatorial type, characterised by a distinct dry season lasting about four months (Aweto 1981). Mean annual rainfall ranges between $1300 \mathrm{~mm}$ and $1600 \mathrm{~mm}$ while the temperature ranged from $24^{0} \mathrm{C}$ to 
$28^{0} \mathrm{C}$. The soils there are ferraltic tropical soils, that are old, deep, highly weathered and red (Areola 1982, Aweto 1981). The soils possess oxic B horizon (a mixture of oxides and aluminium) at a depth of $60 \mathrm{~mm}$ to $150 \mathrm{~mm}$ or $200 \mathrm{~mm}$ (Areola 1982). They were predominantly sand and hence had low fertility status. Thus, the productivity of these soils depended, to a large extent, on the supply of litter by the vegetation. Cassava, maize and sugarcane were the main crops grown in the area.

Data was collected from sample plots established along line transects at varying distances from the source of pollution. Transects were located in four directions of North (N), East (E), South (S) and West (W) from the factory. Plots were established at $1 \mathrm{~km}$ interval, starting from the factory site up to $10 \mathrm{~km}$ in each of the four directions. A sampling quadrat of $20 \mathrm{~m} \mathrm{x}$ $20 \mathrm{~m}$ was demarcated at each plot for data collection.

Within each quadrat, plant species were identified to species level. Woody species were enumerated and their girths measured at breast height. Tree basal area was calculated from the girth measurement and species density was obtained from the field enumeration. Herbaceous species compositions of the plots were established using line-transects. In each plot, five random line-transects were laid. At every metre-point along each transect, a pinpoint peg was dropped and the plant species touched were identified. Leaf abundance and leaf area were estimated for the selected plants (using random sampling technique). Five stands of Manihot esculenta and Saccharum officinarum were randomly picked and all the leaves counted. Total number of leaves per plant is the average number of the leaves on the plant sampled.

The surface area of leaves of Manihot esculenta and Saccharum officinarum was determined using the punch technique described by Nichiporovich (1983). For five randomly selected stands of each plant, all the leaves from the plants were detached and weighed. All the leaves on each randomly selected plant were carefully arranged over one another and a cork borer of known diameter was used to punch the leaves. The discs were also weighed. Three soil samples were collected randomly within each plot with a soil augar at the depth of $0-15 \mathrm{~cm}$. The soil samples were labelled, placed in polythene bags, taken to the laboratory and air-dried. They were passed through $2 \mathrm{~mm}$ sieve before chemical analysis. 
Cassava (Manihot esculenta), which is dicotyledonous, and sugarcane (Saccharum officinarum L.), which is monocotyledonous, were selected for chlorophyll content analysis using the method of Singh and Rao (1981). Both plants were widely distributed in the area. The leaves were washed in distilled water to remove dust particles and weighed. For each species, $0.5 \mathrm{~g}$ of fresh leaf was weighed and ground in $20 \mathrm{ml}$ of $80 \%$ acetone. It was filtered through a double layer of muslin cloth and the filtrate centrifuged at $1000 \mathrm{rpm}$ for 15 minutes. The supernatant was made up to $100 \mathrm{ml}$ with $80 \%$ acetone. Absorbency of supernatant was recorded at $663 \mathrm{~nm}$ and 645 $\mathrm{nm}$ on spectrophotometer (Spectronic 20). Chlorophyll content was estimated according to the method of Bansal et al. (1999).

Soil moisture content was determined according to the procedure outlined by Shingsby and Cook (1986). Soil organic matter was determined using the Walkley-Black method (Black 1965). Available phosphorus was derived by using the Bray No. 1 method (Bray \& Kurtz 1945). Total nitrogen (\%) was determined by the Macro-Kjeldahl method (Black 1965). Soil $\mathrm{pH}$ was determined potentiometrically in $0.01 \mathrm{M}$ calcium chloride solution at a ratio of $1: 2$ (soil to $\mathrm{CaCl}_{2}$ ).

Parameter means and standard deviations were determined for each of the sampled plots. One-way analysis of variance (ANOVA) was used to determine whether there was significant difference in each parameter measured at various distances from the factory site. Regression analysis was employed for those parameters that showed significant difference in means across the sampling sites.

\section{RESULTS}

\section{Vegetation study}

Plant diversity $\left(\mathrm{H}^{1}\right)$ was highest at a distance of $6 \mathrm{~km}$ from the factory site; after this point, there was little change in the species diversity farther away from the factory site (Table 1). The mean tree density ranged from 37.5 to 218 trees. The correlation coefficient between tree density and distance from the factory was 0.7 , suggesting a linear relationship between the two. The regression plot for tree density was $Y=94.89+13.75 X$ and is significant $(P$ $\leq 0.05$, Fig. 1). 
Table 1: Vegetation parameters in relation to distance from Ewekoro Cement Factory, Nigeria (Values are means \pm standard deviations)

\begin{tabular}{|c|c|c|c|c|c|c|}
\hline $\begin{array}{l}\text { Distance } \\
\text { (in } \mathrm{km} \text { ) }\end{array}$ & $\mathrm{H}^{T}$ & $\begin{array}{l}\text { Density } \\
\text { Basal Area } \\
\left(\text { Tree/ha }{ }^{-1}\right) \\
\left(\mathrm{m}^{2} \mathrm{ha}^{-1}\right)\end{array}$ & $\&$ & $\begin{array}{l}\text { Chlorophyll } \\
\text { Concentration } \\
\left(\mathrm{mg}^{\mathrm{g}-1} \text { fresh leaf) }\right. \\
M . \text { esculenta \& } \\
S . \text { officinarum }\end{array}$ & $\begin{array}{l}\text { Leaf Abundance } \\
\left.\text { (plant }^{-1}\right) \\
\text { M. esculenta \& } \\
\text { S. officinarum }\end{array}$ & $\begin{array}{l}\left.\begin{array}{l}\text { Leaf Area } \\
\left(\mathrm{m}^{2} \text { plant }\right.\end{array}{ }^{-1}\right) \\
\text { M.esculenta } \\
\& \quad S . \\
\text { officinarum }\end{array}$ \\
\hline \multirow[t]{2}{*}{0} & 0.2251 & $37.5 \pm 0.0$ & & $1.42 \pm 0.25$ & $21.50 \pm 2.50$ & $0.47 \pm 0.06$ \\
\hline & & $2.37 \pm 0$ & & $0.84 \pm 0.12$ & $8.75 \pm 0.43$ & $0.43 \pm 0.09$ \\
\hline \multirow[t]{2}{*}{1} & 0.7829 & $137.5 \pm 14.5$ & & $1.87 \pm 0.24$ & $21.0 \pm 3.81$ & $0.56 \pm 0.19$ \\
\hline & & $0.49 \pm 0.02$ & & $1.10 \pm 0.14$ & $10.75 \pm 1.64$ & $0.51 \pm 0.11$ \\
\hline \multirow[t]{2}{*}{2} & 0.5961 & $75.0 \pm 8.6$ & & $2.25 \pm 0.14$ & $36.50 \pm 9.86$ & $0.82 \pm 0.24$ \\
\hline & & $0.40 \pm 0.03$ & & $1.43 \pm 0.18$ & $11.00 \pm 0.71$ & $0.49 \pm 0.09$ \\
\hline \multirow[t]{2}{*}{3} & 0.9620 & $118.8 \pm 10.7$ & & $2.67 \pm 0.13$ & $51.50 \pm 10.37$ & $1.18 \pm 0.38$ \\
\hline & & $2.39 \pm 0.24$ & & $1.92 \pm 0.26$ & $12.50 \pm 1.12$ & $0.54 \pm 0.07$ \\
\hline \multirow[t]{2}{*}{4} & 1.3611 & $218.8 \pm 16.9$ & & $3.76 \pm 0.35$ & $66.25 \pm 10.92$ & $1.67 \pm 0.36$ \\
\hline & & $3.11 \pm 0.31$ & & $2.52 \pm 0.33$ & $11.25 \pm .30$ & $0.55 \pm 0.08$ \\
\hline \multirow[t]{2}{*}{5} & 1.1710 & $193.8 \pm 11.8$ & & $4.42 \pm 0.28$ & $59.25 \pm 4.97$ & $1.08 \pm 0.26$ \\
\hline & & $2.02 \pm 0.25$ & & $3.19 \pm 0.34$ & $13.25 \pm 0.83$ & $0.63 \pm 0.03$ \\
\hline \multirow[t]{2}{*}{6} & 1.7736 & $206.3 \pm 12.9$ & & $4.87 \pm 0.19$ & $66.75 \pm 9.44$ & $1.32 \pm 0.18$ \\
\hline & & $2.67 \pm 0.19$ & & $3.38 \pm 0.16$ & $12.00 \pm 1.22$ & $0.58 \pm 0.04$ \\
\hline \multirow[t]{2}{*}{7} & 1.5518 & $212.5 \pm 17.5$ & & $5.06 \pm 0.11$ & $64.8 \pm 12.11$ & $1.46 \pm 0.31$ \\
\hline & & $0.95 \pm 0.04$ & & $3.74 \pm 0.10$ & $14.25 \pm 0.43$ & $0.62 \pm 0.05$ \\
\hline \multirow[t]{2}{*}{8} & 1.5186 & $187.5 \pm 10.9$ & & $5.07 \pm 0.07$ & $71.0 \pm 8.57$ & $1.66 \pm 0.27$ \\
\hline & & $1.18 \pm 0.11$ & & $3.76 \pm 0.15$ & $13.75 \pm 0.83$ & $0.64 \pm 0.03$ \\
\hline \multirow[t]{2}{*}{9} & 1.4945 & $187.5 \pm 9.9$ & & $5.10 \pm 0.07$ & $70.0 \pm 10.65$ & $1.46 \pm 0.27$ \\
\hline & & $0.90 \pm 0.07$ & & $3.78 \pm 0.12$ & $13.75 \pm 0.83$ & $0.64 \pm 0.02$ \\
\hline \multirow[t]{2}{*}{10} & 1.5825 & $193.8 \pm 10.0$ & & $5.08 \pm 0.09$ & $64.75 \pm 12.15$ & $1.41 \pm 0.22$ \\
\hline & & $0.62 \pm 0.02$ & & $3.79 \pm 0.12$ & $13.75 \pm 0.43$ & $0.61 \pm 0.05$ \\
\hline
\end{tabular}

$\mathrm{H}^{\prime}$ : Shannon-Weiner s Index of Diversity. 


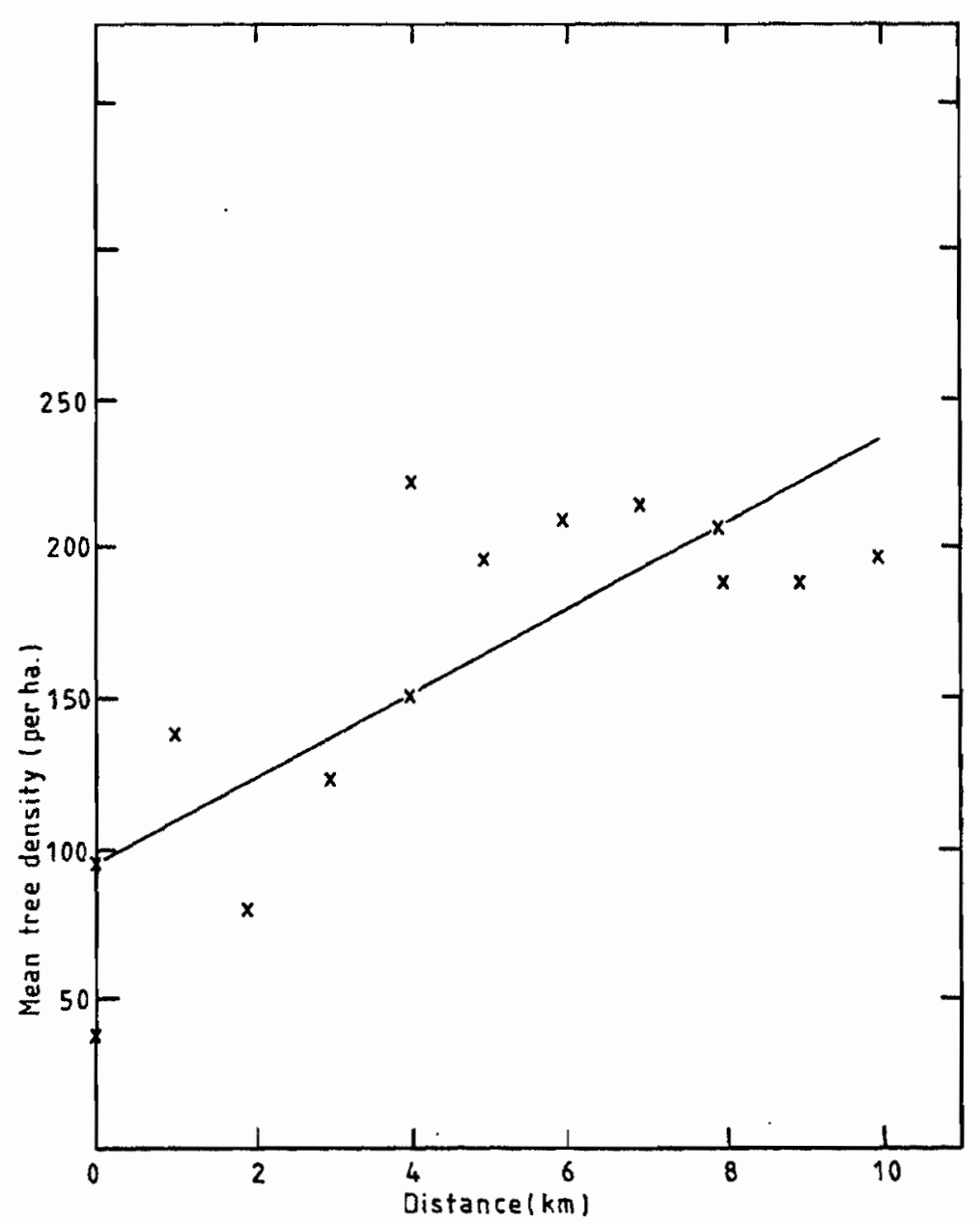

Fig. 1: Regression plot for the tree density against distance from the Ewekoro Cement Factory, Nigeria

The chlorophyll content of the plants increased with increasing distance away from the factory. Visual observations revealed that those plants that were close to the factory had leaves that were chlorotic with dead patches. This became more pronounced as one moved closer to the factory. The highest chlorophyll concentration was obtained at a distance of $9 \mathrm{~km}$ and 10 $\mathrm{km}$ away from the factory for $M$. esculenta and $S$. officinarum respectively. The increase in chlorophyll content of the plants with increasing distance from the factory was significant up to a distance of $5 \mathrm{~km}(\mathrm{P} \leq 0.05, \mathrm{~A} 0 \mathrm{~V}$ test). The increase was insignificant beyond this point. The lines of best-fit 
for the $\operatorname{dicot}(\mathrm{Y}=1.71+0.41 \mathrm{X})$ and monocot $(\mathrm{Y}=1.0+0.34 \mathrm{X})$ were both significant $(\mathrm{P} \leq 0.05$; Fig. 2).

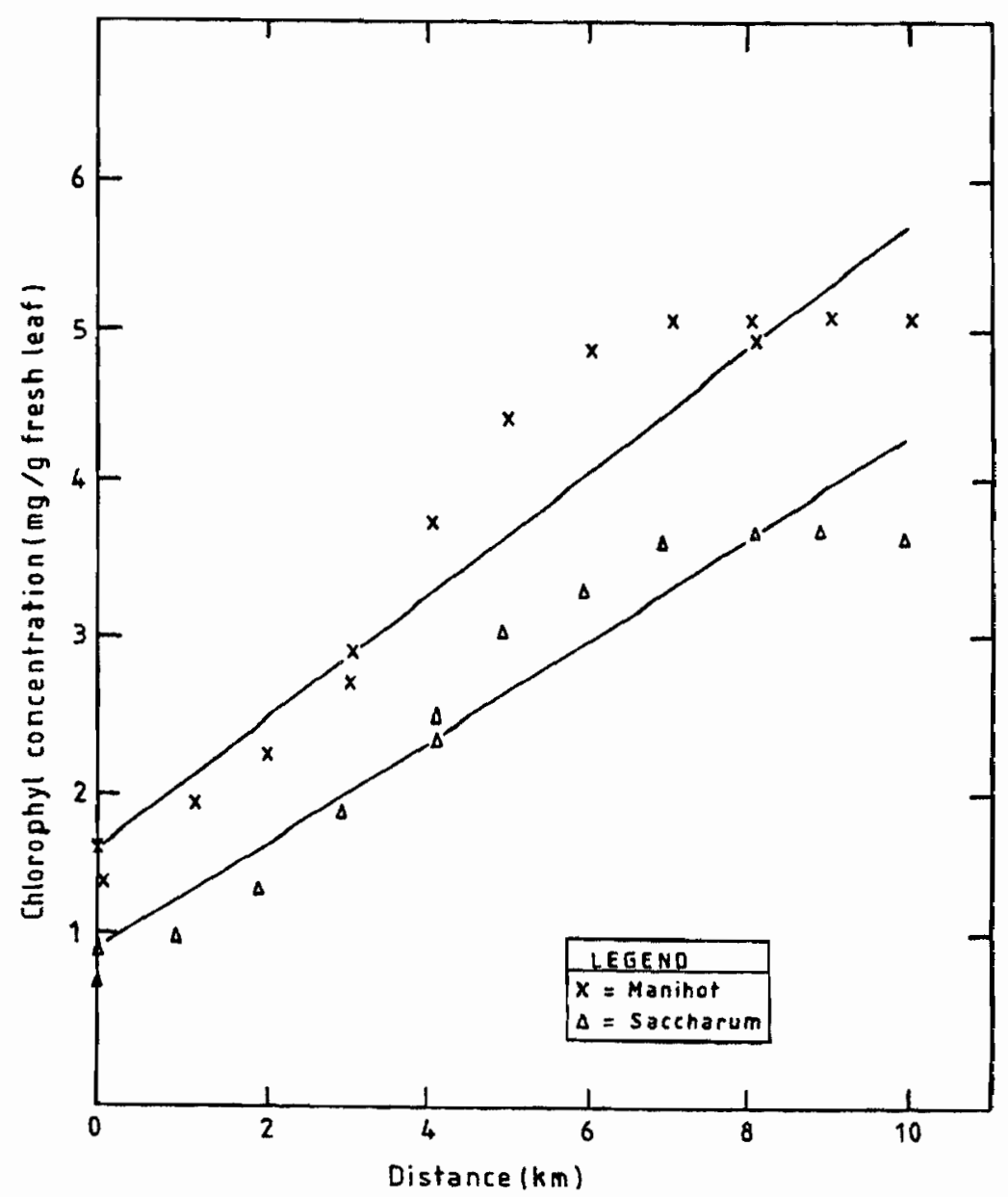

Fig. 2: Regression plot for the chlorophyll content of Mannihot and Saccharum against distance from the Ewekoro Cement Factory, Nigeria

There was significant increase in the number of leaves as well as the leaf area of the plant species with increasing distance from the factory. The lines of best-fit (Figs. $3 \& 4)$ for the dicot leaf abundance $(\mathrm{Y}=28.55+5.63 \mathrm{X})$ and monocot $(Y=10.02+0.45 X)($ Fig. 4$)$ were both significant $(\mathrm{P} \leq 0.05)$. 


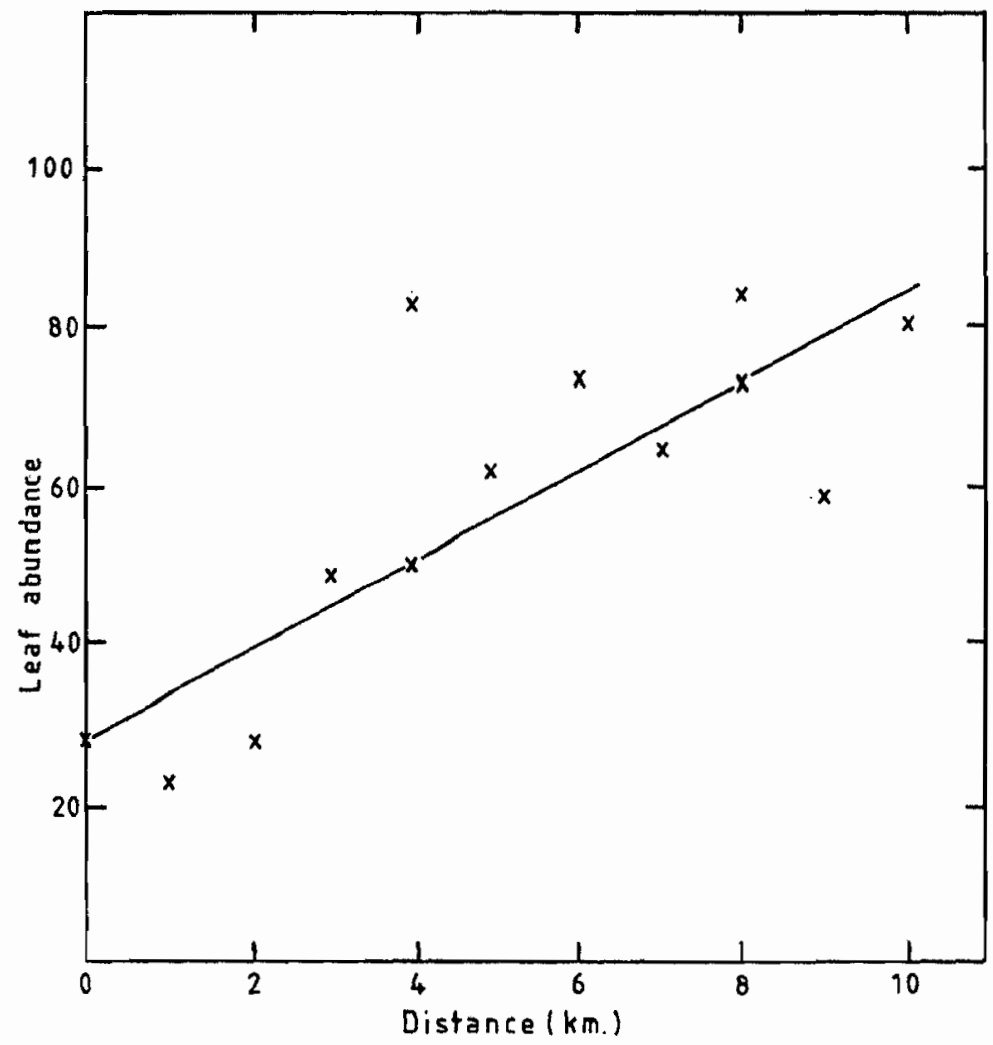

Fig. 3: Regression plot for leaf abundance of Manihot esculenta against distance away from the Ewekoro Cement Factory, Nigeria 


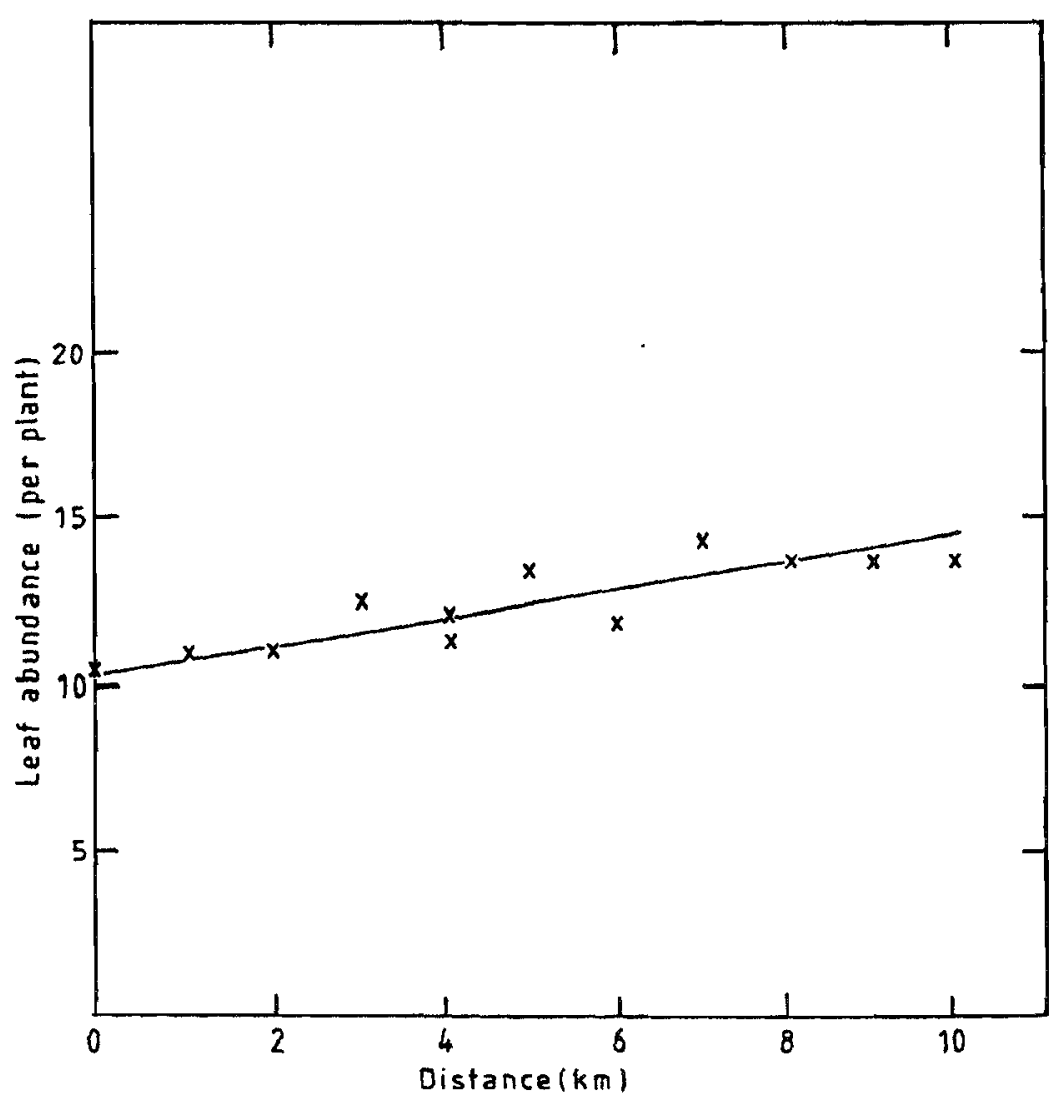

Fig. 4: Regression plot for leaf abundance for Saccharum officinarum against distance from the Ewekoro Cement Factory, Nigeria

\section{Soil study}

The ANOVA (at $\mathrm{P} \leq 0.05$ ) shows that there was no significant difference in soil $\mathrm{pH}$, organic matter content, moisture content and nitrogen content at various distances from the factory (Table 2). However, available phosphorus decreased significantly with increasing distance from the factory $(\mathrm{P} \leq 0.05)$. 
Table 2: Soil parameters in relation to distance from the Ewekoro Cement Factory, Nigeria (Values are means \pm standard deviations)

\begin{tabular}{lllllc}
\hline $\begin{array}{l}\text { Distance } \\
\text { (in } \mathrm{km})\end{array}$ & $\begin{array}{l}\mathrm{pH} \\
\left(\mathrm{CaCl}_{2}\right)\end{array}$ & $\begin{array}{l}\text { Organic matter } \\
(\%)\end{array}$ & $\begin{array}{l}\text { Available } \\
\text { Phosphorus } \\
(\mathrm{ppm})\end{array}$ & $\begin{array}{l}\text { Total } \\
\text { Nitrogen } \\
(\%)\end{array}$ & $\begin{array}{l}\text { Moisture } \\
\text { content } \\
(\%)\end{array}$ \\
\hline 0 & $6.99 \pm 0.06$ & $3.38 \pm 0.18$ & $45.36 \pm 4.18^{\mathrm{b}}$ & $0.15 \pm 0.02$ & $3.64 \pm 1.37$ \\
1 & $6.66 \pm 0.18$ & $2.44 \pm 0.52$ & $44.39 \pm 7.10^{\mathrm{b}}$ & $0.13 \pm 0.02$ & $4.53 \pm 2.15$ \\
2 & $6.83 \pm 0.06$ & $2.47 \pm 0.64$ & $38.39 \pm 6.90^{\mathrm{b}}$ & $0.14 \pm 0.01$ & $4.53 \pm 1.96$ \\
3 & $6.63 \pm 0.19$ & $2.74 \pm 0.45$ & $31.29 \pm 1.79^{\mathrm{b}}$ & $0.14 \pm 0.02$ & $4.22 \pm 2.99$ \\
4 & $6.68 \pm 0.11$ & $3.26 \pm 0.98$ & $29.51 \pm 3.17^{\mathrm{c}}$ & $0.13 \pm 0.01$ & $5.60 \pm 2.25$ \\
5 & $6.68 \pm 0.10$ & $2.95 \pm 0.72$ & $27.28 \pm 1.85^{\mathrm{c}}$ & $0.13 \pm 0.00$ & $5.22 \pm 1.68$ \\
6 & $6.54 \pm 0.19$ & $2.75 \pm 0.38$ & $26.84 \pm 1.78^{\mathrm{a}}$ & $0.14 \pm 0.00$ & $6.43 \pm 0.59$ \\
7 & $6.59 \pm 0.25$ & $2.21 \pm 1.21$ & $26.88 \pm 1.72^{\mathrm{e}}$ & $0.14 \pm 0.02$ & $6.05 \pm 1.58$ \\
8 & $6.65 \pm 0.22$ & $2.54 \pm 1.01$ & $27.79 \pm 1.24^{\mathrm{d}}$ & $0.15 \pm 0.02$ & $4.17 \pm 1.76$ \\
9 & $6.70 \pm 0.09$ & $2.53 \pm 0.73$ & $26.64 \pm 1.29^{\text {ad }}$ & $0.13 \pm 0.02$ & $4.53 \pm 1.01$ \\
10 & $6.54 \pm 0.20$ & $1.95 \pm 0.55$ & $26.42 \pm 1.30^{\mathrm{d}}$ & $0.13 \pm 0.02$ & $5.20 \pm 0.70$ \\
\hline
\end{tabular}

Values in columns followed by the same letters are not significant according to Duncan $\mathrm{s}$ Multiple Range Test $(\mathrm{P} \leq 0.05)$

\section{DISCUSSION}

The vegetation of the study area was a regrowth as evidenced by the basal area of woody species, which were generally small (Salami et al. 2002). The woody species dotted the terrain, while the grass and forbs species formed the ground cover. This conforms with the results obtained by Muoghalu (1996) in his study of vegetation around Nkalagu cement factory. Forest regrowth species such as Raufolvia vomitoria, Albizia zygia, Alchornea cordifolia, Ficus exasperata and Spondias mombin that were widely distributed in the area is an indication of early stages of secondary forest regrowth. Oke and Isichei (1997) noted that the presence of such species is a reflection of moderately intense past land-use and are characteristic of fallow in the African forest region.

The trend of the increase in chlorophyll content of plants, obtained in the present study, is also similar to that reported by Odu (1994), and is possibly due to the decrease in the deposition of cement dust with increasing distance from the factory (Akeredolu et al. 1994). Reduction in chlorophyll content, as a result of cement dust deposition has been reported for Helianthus annuus (Borka 1980), Triticum aestivum (Singh \& Rao 1981), Zea mays, Amaranthus viridis and Abelmoscus esculentus (Odu 1994). Singh and Rao (1981) noted that changes associated with chlorophyll content in a cement-polluted environment, were associated with a decrease in the levels of stomatal and cuticular transpiration of encrusted leaf surfaces. The 
alkaline cement, incorporated into leaf tissues, results in chloroplast damage and leads to a reduction in total chlorophyll in the leaves. The reduction in total chlorophyll would invariably lead to a reduction in the primary productivity of the producers in such a polluted environment (Lal \& Ambasht 1982). The results obtained from the foliage study show that cement dust pollution affected both leaf abundance (per plant) and its area. Plants leaves close to the factory site were chlorotic. The physiological effects associated with such chlorosis and drying-off make the leaves to whither and defoliate prematurely, hence the reduction in the leaf number observed in plants around the factory area. This observation reinforces the submission of Hosker and Linderberg (1982) and Hinrichsen (1986), that visible injuries and impairment of physiological functions accompany chronic exposure of plants to atmospheric pollutants. Pawar et al. (1982) made similar observations with respect to the leaves of Hibiscus abelmoscus. Dead patches, chlorosis and drying-off will affect the chlorophyll content of a leaf. These effects together with the premature leaf defoliate that accompany them could lead to reduced primary productivity of the producers in such an ecosystem.

Soil $\mathrm{pH}$, organic matter content, nitrogen and moisture contents showed no significant difference in values across the sampling plots $(\mathrm{P} \leq 0.05)$. Smyth and Montgomery (1962) as well as Jeje and Ekanade (1988) observed that there could be no major differences between soils, which are derived from chemically similar rocks under essentially uniform conditions of climate and overall vegetation. More phosphorus was available around the factory site. Phosphorus is one of the components of cement and it is deposited along with cement dust (Asubiojo 1991). The high concentration of phosphorus in the soils around the cement factory might also have origin other than the atmospheric deposition of cement dust around the neighbourhood of the factory. The marble used in manufacturing cement contains phosphorus. Ewekoro factory obtained its marble within a distance of 1-2 km West of the factory and this could account for intrinsically high phosphorus concentration around the area.

Cement dust deposition had both visible and physiological impact on the vegetation around Ewekoro. Since the deposition lowered the chlorophyll synthesis significantly, then, the primary productivity of the area would be lower than that of cement-dust-free-environment. The present study however indicates that the impact of cement dust deposition on plants was 
limited to a distance of about $5 \mathrm{~km}$ from the factory site. Ewekoro Cement Factory was established about 40 years ago. Almost all the tree species encountered in this study are forest regrowth species with small basal areas. It could therefore be inferred that these tree species are less than 40 years and this implies that the cement dust pollution did not prevent the appearance and growth of tree species, although it might have affected their growth rate. This suggests that the impact of land-use, especially farming system in the area (Salami 2001), had reinforced the effect of the factory pollution on the vegetation of the area. The most frequent tree species encountered in this study Nauclea latifolia, is a savanna species and it had a wide distribution in the area together with some other savanna species like Terminalia glaucescens. These species coexisted with forest regrowth species. The influence of annual fires in the study area might give the savanna species a competitive advantage and eventually aid the transition of the area from a forest to savanna ecosystem. Nevertheless, the appearance of forest regrowth species in the area means that the original forest cover can still be restored with appropriate land-use management systems.

\section{REFERENCES}

Akeredolu FA, Olaniyi HB, Adejumo JA, Obioh IB, Asubiojo OI and Oluwole AF 1994 Determination of elemental composition of TSP from cement industries in Nigeria using EXDRF techniques. Nuclear Instrument and Methods in Physics Research A353: 542-545

Areola O 1982 Soils In: Barbour KM, Oguntoyinbo JS, Onyemelukwe JOC and Nwafor JC (eds.). Nigeria in Maps. Houdder and Stoughton, London

Asubiojo OI 1991 Effects of cement production on the elemental composition of soils in the neighbourhood of two cement factories. Air, Water and soil Pollution 57/58: 819

Aweto AO 1981 Fallowing and soil fertility restoration in South-west Nigeria. Malaysian Journal of Tropical Geography 3: 1-6

Bansal UK, Saini RG and Kaur A 1999 Genetic variability in leaf area and Chlorophyll content. International Rice Research Notes 24 (1): 21

Black CA 1965 Methods of soil analysis II: Chemical and microbiological properties. American Society of Agronomy, Madison 
Borka G 1980 The effect of cement dust pollution on growth and metabolism of Helianthus annus. Environmental Pollution 22: 75-79

Bray RH and Kurtz LT 1945 Determination of total organic and available forms of Phosphorus in soils. Soil Science 59: 39-46

Fukuzaki N, Tamura R, Hiramo Y and Mizushima Y 1986 Mercury emission from a cement factory and its influence on the environment. Atmospheric Environment 20 (12): 2291-2299

Hinrichsen D 1986 Multiple Pollutant and forest decline. Ambio 15: 258265

Hosker RP and Linderberg SE 1982 Atmospheric deposition and plant assimilation of gases and particles. Atmospheric Environment 16 (5): $889-910$

Jeje LK and Ekanade O 1988 Variations in soils of a common class. Ife Research Publications in Geography 2: 27-38

Lal B and Ambasht RS 1982 Impact of cement dust on the mineral and energy concentration of Psidium guajava. Environmental Pollution 29: 241-247

Muoghalu JI 1996 The vegetation of a cement manufacturing town in Nigeria after 36 years of limestone quarrying. Nigerian Journal of Botany, 9: $1-8$

Nichiporovich AA 1983 Determination of leaf area of soybean plant, In: Bawanov BF, Lebedovskii AI and Teventier IN (Eds.) Methodology of field agro-technical experiments on soybeans and their observations Vsesoyuznar Ordena Lenina Akademii Sel skokhozyaistvennykh Nauk Im V.I. Lenina, Krasnodar, 7

Odu EA 1994 Impact of cement dust emission on leaf chlorophyll of agricultural crops. EEC Proceedings on Environmetal Monitoring and Impact Assessment Seminar 404-410

Oke SO and Isichei AO 1997 Floristic and structure of fallow vegetation in the Ile-Ife area of southwestern Nigeria. Nigerian Journal of Botany 10: $37-50$

Oyedele DJ, Aina PO, Oluwole F and Asubiojo IO 1990 Preliminary Assessment of pollution effect of cement dust on soil and biomass production. A Seminar paper delivered at $18^{\text {th }}$ annual conference of the Nigerian Soil Society, University of Maiduguri, Maiduguri, Nigeria 
Pawar K, Trivedi L and Dubey PS 1982 Comparative effects of cement, coal dust and fly-ash on Hibiscus abelmoschus. International Journal of Environmental Studies 19: 221-223

Salami AT 2001 Agricultural colonisation and floristic degradation in Nigeria s rainforest ecosystem. The Environmentalist 21: 221229

Salami AT, Jimoh MA and Muoghalu JI 2002 Impact of gold mining on vegetation and soil in southwestern Nigeria. International Journal of Environmental Studies (in press).

Shingsby D and Cook C 1986 Practical Ecology. Macmillan Press Ltd., London

Singh SN and Rao DN 1981 Certain responses of wheat plants to cement dust pollution. Environmental Pollution 24: 75-81

Smyth AJ and Montgomery RF 1962 Soils and Land Use in Central Western Nigeria. Government printers, Ibadan 